\title{
Diversification of Bromelioideae (Bromeliaceae) in the Brazilian Atlantic rainforest: A case study in Aechmea subgenus Ortgiesia ${ }^{\text {is }}$
}

\author{
Márcia Goetze $^{\mathrm{a}}$, Katharina Schulte ${ }^{\mathrm{b}, \mathrm{c}}$, Clarisse Palma-Silva ${ }^{\mathrm{d}}$, Camila M. Zanella ${ }^{\mathrm{a}}$, Miriam V. Büttow ${ }^{\mathrm{a}}$, \\ Fernanda Capra ${ }^{\mathrm{a}}$, Fernanda Bered ${ }^{\mathrm{a}, *}$

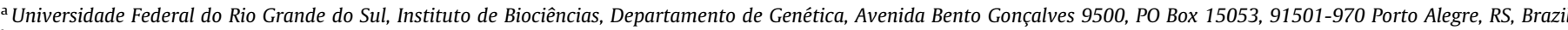 \\ b Australian Tropical Herbarium, James Cook University, PO Box 6811, Cairns, QLD 4878, Australia \\ 'Centre for Tropical Biodiversity and Climate Change, James Cook University, Discovery Drive, Townsville, QLD 4814, Australia \\ ${ }^{\mathrm{d}}$ Universidade Estadual Paulista Júlio de Mesquita Filho, Instituto de Biociências, Departamento de Ecologia, Avenida 24A 1515, 13506-900 Rio Claro, SP, Brazil
}

\section{A R T I C L E I N F O}

\section{Article history:}

Received 29 December 2014

Revised 26 December 2015

Accepted 1 March 2016

Available online 5 March 2016

\section{Keywords:}

Aechmea

AFLP

Biogeography

Core bromelioids

Interspecific relationships

Speciation

\begin{abstract}
A B S T R A C T
Aechmea subgenus Ortgiesia comprises ca. 20 species distributed in Brazil, Argentina, Paraguay, and Uruguay, with a center of diversity in the Brazilian Atlantic rainforest. We examined interspecific relationships of Ortgiesia based on Amplified Fragment Length Polymorphisms (AFLP). Ninety-six accessions belonging to 14 species of Ortgiesia were sampled, and genotyped with 11 AFLP primer combinations. The neighbor joining ( $\mathrm{NJ}$ ) tree depicted two main genetic groups within Aechmea subgenus Ortgiesia, and four subgroups. The NJ tree showed short internal branches, indicating an overall shallow genetic divergence among Ortgiesia species as expected for the recently radiated subfamily Bromelioideae. Our results suggest that hybridization and/or incomplete lineage sorting may have hampered the reconstruction of interspecific relationships in Aechmea subgenus Ortgiesia. The mapping of petal color (yellow, blue, pink, or white), inflorescence type (simple or compound), and inflorescence shape (ellipsoid, subcylindric, cylindric, or pyramidal) against the $\mathrm{NJ}$ tree indicated that these characters are of limited taxonomic use in Aechmea subgenus Ortgiesia due to homoplasy. An analysis of the current distribution of Ortgiesia identified the southern region of the Brazilian Atlantic rainforest, between latitudes of $26^{\circ}$ and $27^{\circ} \mathrm{S}$, as the center of diversity for the subgenus.
\end{abstract}

(c) 2016 Elsevier Inc. All rights reserved.

\section{Introduction}

The Brazilian Atlantic rainforest represents one of the top five biodiversity hotspots on Earth, with high levels of endemism (Myers et al., 2000). Despite its reduction to only $11-16 \%$ of its original area (Ribeiro et al., 2009), it is home to more than 15,000 plant species of which $45 \%$ are endemic to this biome (Stehmann et al., 2009). Bromeliaceae, the second largest family among vascular epiphytes in the Neotropics, are an important and characteristic element of the Atlantic rainforest, being represented by 816 species of which 651 are endemic (Stehmann et al., 2009). Bromeliads play an important ecological role due to their interaction with fauna, as sources for pollen, nectar, fruit,

\footnotetext{
This paper was edited by the Associate Editor Timothy Evans.

* Corresponding author.

E-mail addresses: marciagoetze@yahoo.com.br (M. Goetze), katharina.schulte@ jcu.edu.au (K. Schulte), clarissepalma@yahoo.com.br (C. Palma-Silva), milamzanella@gmail.com (C.M. Zanella), miriamvb@gmail.com (M.V. Büttow), fecap@hotmail.com (F. Capra), fernanda.bered@ufrgs.br (F. Bered).
}

and water, as well as for providing microhabitats for many invertebrates and even vertebrates (Benzing, 2000). For subfamily Bromelioideae (33 genera and 936 species; Luther, 2012) the Atlantic rainforest is the center of diversity with ca. 505 species (Martinelli et al., 2008) including ten genera endemic to this biome (Smith and Downs, 1979; Stehmann et al., 2009).

Subfamily Bromelioideae is morphologically and ecologically highly diverse, comprising terrestrial, lithophytic and epiphytic life-forms. Molecular phylogenetic studies have revealed that Bromelioideae comprise several small lineages, which diverged early in the evolution of the group, and the core bromelioid clade, which harbors the majority of species (Schulte and Zizka, 2008; Schulte et al., 2005, 2009; Silvestro et al., 2014). Recent molecular phylogenetic studies inferred an Andean origin of the subfamily in the late Miocene, at around $13 \mathrm{Ma}$, and an early migration to Eastern Brazil via a central South American corridor, at around $10 \mathrm{Ma}$ (Schulte et al., 2005; Silvestro et al., 2014). Whereas the early diverging Bromelioideae lineages were terrestrials and lithophytes, the acquisition of a central water impounding structure, the tank, facilitated the core bromelioid's invasion of the epiphytic niche, 
especially within the Atlantic rainforest, where they diversified extensively (Givnish et al., 2011; Schulte et al., 2009; Silvestro et al., 2014).

Aechmea subgenus Ortgiesia belongs to the tank-forming core bromelioid clade (Sass and Specht, 2010; Schulte et al., 2009; Silvestro et al., 2014), and comprises ca. 20 species (Luther, 2010), most of which are endemic to the Atlantic rainforest (Smith and Downs, 1979). The subgenus occurs in south and southeastern Brazil (Espírito Santo to Rio Grande do Sul states), mainly in the subtropical area, with several narrow endemic species, some only known from the type collection. Two more widespread species, Aechmea calyculata and A. recurvata, also expand to the west and reach into Argentina, Paraguay, and Uruguay (Smith and Downs, 1979). Ortgiesia species are encountered from sea level to 1200 m elevation as epiphytes, lithophytes, or terrestrials (Reitz, 1983; Smith and Downs, 1979; Wanderley and Martins, 2007).

Previous molecular phylogenetic studies included only a limited number of representatives of subgenus Ortgiesia. These studies demonstrated a close phylogenetic relationship between most of the investigated species, albeit the monophyly of the subgenus was not confirmed (Horres et al., 2007; Schulte and Zizka, 2008; Schulte et al., 2009; Silvestro et al., 2014). In several studies, Aechmea racinae L.B.Sm. (subgenus Lamprococcus) was nested within Ortgiesia (Horres et al., 2007; Schulte and Zizka, 2008; Schulte et al., 2005; Silvestro et al., 2014) or found in sister group position to an Ortgiesia clade (Schulte et al., 2009). In the molecular phylogenetic study of Sass and Specht (2010), the eight Ortgiesia species included formed a clade together, however Billbergia zebrina Lindl. was nested within this clade. So far, interspecific relationships within Ortgiesia remained unclear due to limited resolution of phylogenetic reconstructions, which may be due to the relative young age of the extant species of the subgenus. In a recent age estimate based on molecular dating analysis of a multi-locus phylogeny of the subfamily Bromelioideae, the crown diversification of Ortgiesia was estimated to have started during the late Pliocene, at around $2.5 \mathrm{Ma}$ (Silvestro et al., 2014).

Floral features, in particular the petal color and the inflorescence branching pattern, have been given much emphasis in the taxonomy and systematics of Aechmea subgenus Ortgiesia (Smith and Downs, 1979). Petal color in Ortgiesia is mostly yellow or blue, sometimes pink or white, and intermediate colors are rare exceptions (M. Goetze, personal observation). A great diversity is found in inflorescence morphology, which varies from simple to compound, dense to lax, few to many flowered, with many intermediate forms, thus rendering the delimitation of species boundaries difficult (Faria et al., 2004; Smith and Downs, 1979; Wanderley and Martins, 2007). The lack of detailed molecular phylogenetic studies in Ortgiesia has hampered the evaluation of morphological characters and their taxonomic value.

Previous phylogenetic studies in Bromeliaceae have demonstrated very low DNA sequence variation of the plastid and nuclear markers used (e.g., Barfuss et al., 2005; De Sousa et al., 2007; Horres et al., 2007; Louzada et al., 2014; Maia et al., 2012; Schulte et al., 2009; Versieux et al., 2012), which has rendered the assessment of intra- and interspecific relationships difficult. Amplified fragment length polymorphisms (AFLP) have been successfully used to elucidate interspecific relationship in closely related Bromeliaceae (Heller et al., 2015; Horres et al., 2007; Jabaily and Sytsma, 2013; Rex et al., 2007; Schulte et al., 2010). The AFLP technique provides numerous genetic markers that are distributed across the whole genome and usually exhibit moderate to high rates of variability. AFLPs require no prior knowledge of the genome analyzed, and have been proven to be a time and cost efficient tool in assessing interspecific relationships in complex plant groups (Gaudeul et al., 2012; Meudt and Clarke, 2007).
This study aims to gain insights into the diversification of Aechmea subgenus Ortgiesia in the Atlantic rainforest. To this aim, we (1) reconstructed interspecific relationships in Ortgiesia based on AFLP data, (2) assessed the taxonomic value of key morphological characters, and (3) examined biogeographic patterns in Ortgiesia.

\section{Materials and methods}

\subsection{Plant material}

A total of 96 individuals belonging to 13 Aechmea species of subgenus Ortgiesia, one undescribed and potentially new taxon (here referred to as Aechmea sp.), plus A. kleinii, originally described as belonging to Ortgiesia but included in subgenus Pothuava by Smith and Downs (1979) and Luther (2010), were sampled along the geographical distribution of the group in the Brazilian Atlantic rainforest (Table 1; Fig. 1). As outgroup five species from the Nidularioid clade were included. Fresh leaves of 1-9 individuals per species were sampled and dried using silica gel. Voucher information is provided in Table 1.

\subsection{AFLP procedures}

Total genomic DNA was extracted with the CTAB method following Doyle and Doyle (1990). Amplified fragment length polymorphism protocols followed Vos et al. (1995) with modifications as outlined by Schulte et al. (2010). Briefly, $30 \mathrm{ng}$ of genomic DNA were digested with the restriction enzymes Hin-

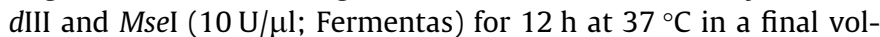
ume of $30 \mu \mathrm{l}$, and ligated to HindIII and MseI adapters in the same reaction using T4 DNA ligase $(5 \mathrm{U} / \mu \mathrm{l}$; Fermentas). Preselective amplifications were carried out with primers with one selective base each (HindIII-A and MseI-C, respectively) in a total volume of $10 \mu \mathrm{l}$ containing $2 \mu \mathrm{l}$ of the $1: 10$ diluted restrictionligation product, $1 \times$ Taq buffer (Kapa Biosystems, Boston, USA), $0.5 \mu \mathrm{M}$ of each primer, $2 \mathrm{mM}$ of dNTP mix, and $0.25 \mathrm{U}$ of Taq DNA polymerase (Kapa Biosystems). Assays were subjected to 30 cycles of amplification, each consisting of $94^{\circ} \mathrm{C}$ for $20 \mathrm{~s}, 56^{\circ} \mathrm{C}$ for $30 \mathrm{~s}$, and $72{ }^{\circ} \mathrm{C}$ for $2 \mathrm{~min}$. Final extension was at $72{ }^{\circ} \mathrm{C}$ for $2 \mathrm{~min}$, followed by $60^{\circ} \mathrm{C}$ for $30 \mathrm{~min}$. Selective amplifications were run with primers carrying three selective bases each (see below), and with fluorescently labeled HindIII primers (FAM, NED, or VIC; Applied Biosystems), with $2.5 \mu$ of 1:20 diluted pre-selective PCR product, $1 \times$ Taq buffer (Kapa Biosystems), $0.5 \mu \mathrm{M}$ of each primer, $2 \mathrm{mM}$ of dNTP mix, and $0.25 \mathrm{U}$ of Taq DNA polymerase (Kapa Biosystems). Assays were subjected to a touchdown protocol as described by Schulte et al. (2010). Primer screening was carried out with 54 primer combinations and eight representative Ortgiesia samples. Based on the resulting banding patterns, eleven primer combinations were chosen for the generation of the final AFLP profiles: (1) H-ACA and M-CAA, (2) H-AGC and M-CGA, (3) H-AAC and $M$-CTG, (4) H-ACA and M-CTA, (5) H-AGC and M-CTG, (6) H-AAC and $M$-CGA, (7) $H$-ACC and $M$-CAG, (8) $H$-AGC and $M$-CTA, (9) $H$ ACT and M-CAG, (10) $H$-ACA and M-CTC, and (11) $H$-ACA and $M$ CAT. To assess the accuracy and reproducibility of the AFLP markers, a subset of samples was run independently for each primer pair. Comparisons of the results from the two independent runs were satisfactory, yielding highly similar and reproducible banding patterns. Amplification products were electrophoresed at the Australian Genome Research Facility Ltd (Brisbane, Australia) on an AB3730 DNA analyzer (Applied Biosystems). Molecular sizes in base pairs were determined using the GeneScan-500 LIZ size standard. 
Table 1

Accessions data for the populations of Aechmea subgenus Ortgiesia collected.

\begin{tabular}{|c|c|c|c|}
\hline Species (N)/Population code & Location & Sample ID & Voucher \\
\hline \multicolumn{4}{|l|}{ A. blumenavii Reitz (8) } \\
\hline BLP & Blumenau - SC & $611,612,616,617$ & FURB 13803 \\
\hline BLM & Blumenau - SC & $632,633,640,642$ & FURB 27979 \\
\hline \multicolumn{4}{|l|}{ A. calyculata (E. Morren) Baker (9) } \\
\hline DER & Derrubadas - RS & 325,327 & HAS 66416 \\
\hline $\mathrm{CON}$ & Concórdia - SC & 530 & FURB 34426 \\
\hline BAR & Barracão - RS & 516 & ICN 119812 \\
\hline PUT & Putinga - RS & 581 & HAVT 46 \\
\hline MAQ & Maquiné - RS & 429,431 & HAS 36048 \\
\hline SFR & São Francisco de Paula - RS & 480,510 & ICN 165253 \\
\hline $\begin{array}{l}\text { A. candida E. Morren ex Baker (1) } \\
\text { GUA }\end{array}$ & \multicolumn{2}{|c|}{ A. candida E. Morren ex Baker (1) } & ICN 178781 \\
\hline \multicolumn{4}{|l|}{ A. caudata Lindm. (6) } \\
\hline GAR & Guarujá - SP & 08 & SP 385012 \\
\hline ILH & Ilhota - SC & 56 & FURB 14688 \\
\hline LAU & Lauro Müller - SC & 59 & HAS 66425 \\
\hline ARA & Araquari - SC & 170 & FURB 28062 \\
\hline FLO & Florianópolis - SC & 239,266 & FURB 22585 \\
\hline \multicolumn{4}{|l|}{ A. coelestis (K. Koch) E. Morren (9) } \\
\hline UBA & Ubatuba - SP & $09,15,17,20$ & SP 39027 \\
\hline STE & Santa Teresa - ES & $291,292,295$ & T.S. Coser $321(\mathrm{R})$ \\
\hline SMJ & Santa Maria de Jetibá - ES & 305,306 & T.S. Coser 341 (R) \\
\hline \multicolumn{4}{|l|}{ A. comata Baker (8) } \\
\hline FLN & Florianópolis - SC & 196, 199, 203, 205 & ICN 165256 \\
\hline FLO & Florianópolis - SC & $648,649,650,655$ & FURB 22579 \\
\hline \multicolumn{4}{|l|}{ A. cylindrata Lindm. (1) } \\
\hline SGR & Serra da Graciosa - PR & 363 & MBM 180463 \\
\hline \multicolumn{4}{|l|}{ A. gamosepala Wittm. (4) } \\
\hline SDF & Serra Dona Francisca - SC & 154,156 & ICN 191154 \\
\hline MAT & Matinhos - PR & 421,422 & ICN 165259 \\
\hline \multicolumn{4}{|l|}{ A. gracilis Lindm. (9) } \\
\hline PAR & Pariquera-Açu - SP & $02,03,07$ & B.F. Abonanza 13 (SP) \\
\hline IPO & Iporanga - SP & 283,284 & B.F. Abonanza 23 (SP) \\
\hline SGR & Serra da Graciosa - PR & $386,392,396,407$ & ICN 191151 \\
\hline \multicolumn{4}{|l|}{ A. kertesziae Reitz (9) } \\
\hline ITA & Itajaí - SC & $102,588,600$ & ICN 191153 \\
\hline BOM & Bombinhas - SC & 659,664 & CESJ 62360 \\
\hline FLN & Florianópolis - SC & 219,734 & UPBC 35253 \\
\hline LAG & Laguna - SC & 40,44 & ICN 167498 \\
\hline \multicolumn{4}{|l|}{ A. kleinii Reitz (3) } \\
\hline ANT & Antônio Carlos - SC & $278,279,280$ & ICN 167501 \\
\hline \multicolumn{4}{|l|}{ A. organensis Wawra (8) } \\
\hline TER & Teresópolis - RJ & 731 & B.F. Abonanza 17 (SP) \\
\hline INT & Intervales - SP & 732 & B.F. Abonanza 26 (SP) \\
\hline SGR & Serra da Graciosa - PR & $388,397,398,404,406,736$ & ICN 191150 \\
\hline \multicolumn{4}{|l|}{ A. recurvata (Klotzsch) L.B. Sm. (8) } \\
\hline VIA & Viamão - RS & $29,20,31,32$ & ICN 115402 \\
\hline ITA & Itajaí - SC & $119,120,121$ & FURB 14370 \\
\hline MON & Monte Castelo - SC & 737 & ICN 191149 \\
\hline \multicolumn{4}{|l|}{ A. $\mathrm{sp}(5)$} \\
\hline TAP & Tapiraí - SP & $312,313,314,315,316$ & B.F. Abonanza 3 (SP) \\
\hline \multicolumn{4}{|l|}{ A. winkleri Reitz (8) } \\
\hline COR & Corupá - SC & $130,133,140,739$ & ICN 191152 \\
\hline SCR & Santa Cruz do Sul - RS & $176,178,181,735$ & ICN 189267 \\
\hline \multicolumn{4}{|l|}{ Outgroup } \\
\hline Neoregelia laevis (Mez) L.B. Sm. & Serra da Graciosa - PR & 705 & ICN 190907 \\
\hline Nidularium billbergioides (Schult. f.) L.B. Sm. & Garuva - SC & 710 & UPCB 22872 \\
\hline N. innocentii Lem. & Serra Dona Francisca - SC & 706 & FURB 20521 \\
\hline Wittrockia superba Lindm. & Jacinto Machado - SC & 726 & FURB 25282 \\
\hline
\end{tabular}

N, sample size. Brazilian federal states: ES, Espírito Santo; RJ, Rio de Janeiro; SP, São Paulo; PR, Paraná; SC, Santa Catarina; RS, Rio Grande do Sul.

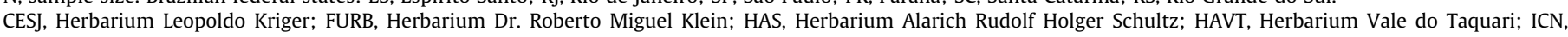

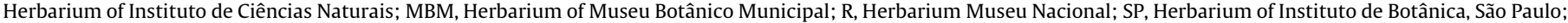
UPBC, Herbarium Departamento de Botânica, Universidade Federal do Paraná.

Genotypes were automatically scored in GeneMarker version 1.97 (SoftGenetics, Pennsylvania, USA) using the AFLP analysis tool, carefully cross-checked, and manually edited where required.
Fragments of a size range between 90 and 400 base pairs and with signal strengths above an intensity score of 500 were scored as a binary presence/absence matrix (1/0). 


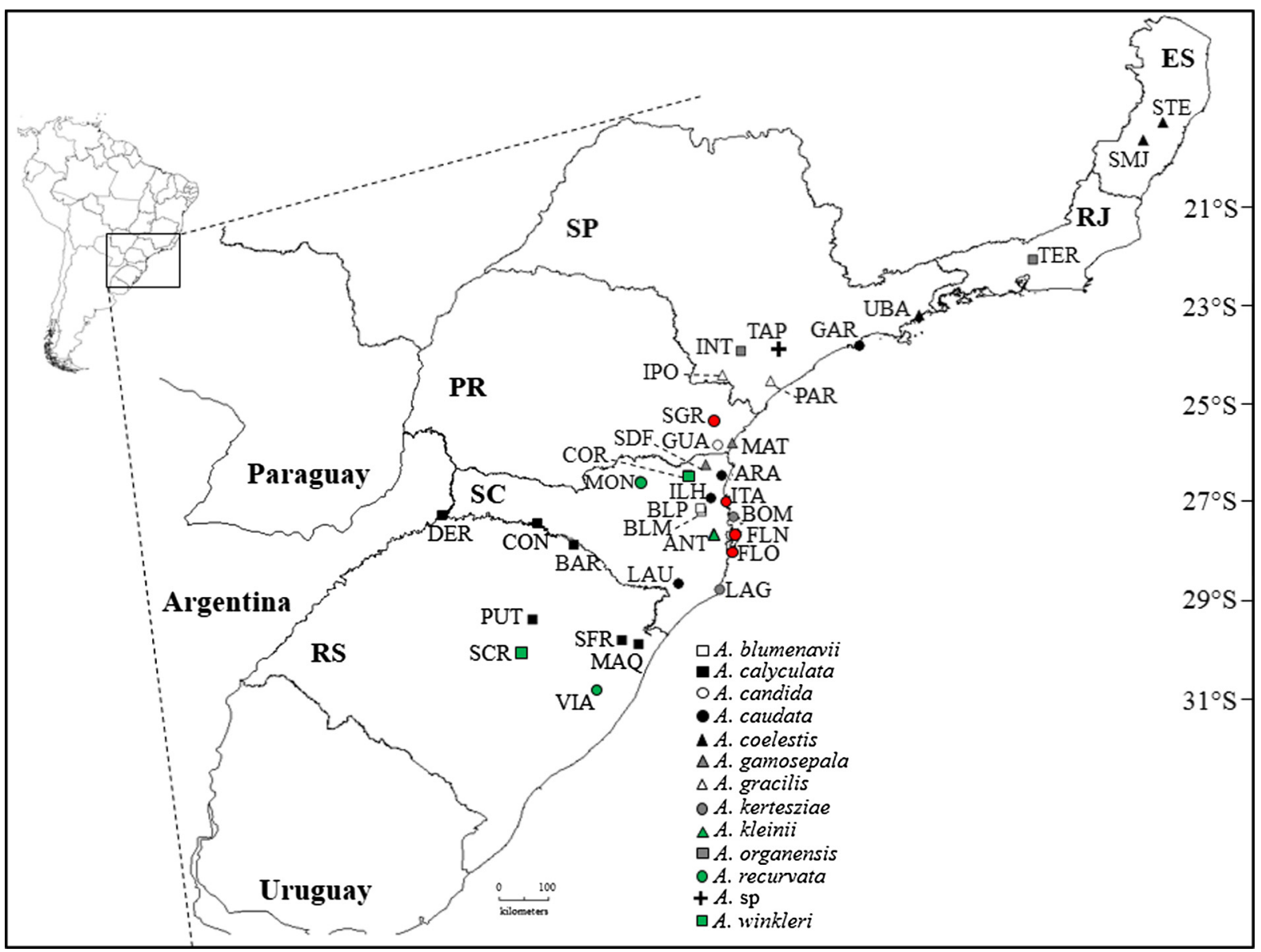

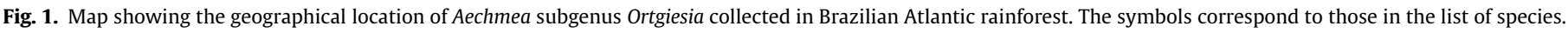

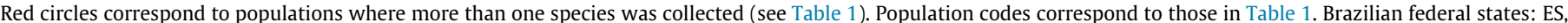

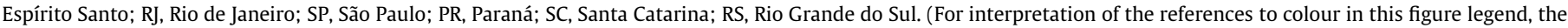
reader is referred to the web version of this article.)

\subsection{AFLP data analyses}

AFLP matrices of all 11 primer combinations were concatenated to a single matrix and analyzed jointly. Interspecific relationships were reconstructed by neighbor-joining (NJ) analysis (Saitou and Nei, 1987) using Nei-Li's distance measure (Nei and Li, 1979) in PAUP* version 4.0b10 (Swofford, 2002). Statistical support values for nodes and clades were estimated by bootstrap analysis with 1000 replicates (Felsenstein, 1985).

Bayesian phylogenetic analysis was conducted in MrBayes 3.2 (Ronquist and Huelsenbeck, 2003), using the restriction site model and the prior lset coding = noabsencesites. Three simultaneous chains were run for 10 million generations each, sampled every 100 th, and the default setting to discard the first $25 \%$ of the trees as burn-in. Convergence and stationarity of the MrBayes analysis were determined by evaluating the standard deviation of split frequency values of the end of the run, and by checking run convergence in TRACER 1.5 (available at http://beast.bio.ed.ac.uk/Tracer).

To quantify the amount of genetic differentiation among species, an Analysis of Molecular Variance (AMOVA) was performed in the program ARLEQUIN version 3.11 (Excoffier et al., 2005) under 10,000 permutations. Only species with more than one population sampled were included in this analysis (see Table 1 ).

\subsection{Morphological character coding and mapping}

Three morphological characters were evaluated to examine their taxonomic utility. Petal color (yellow, blue, pink, or white) and inflorescence type (simple or compound) are important characters used in species identification of Aechmea subgenus Ortgiesia (Smith and Downs, 1979). The third character included in this study, inflorescence shape (ellipsoid, subcylindric, cylindric, or pyramidal), has not previously been emphasized in taxonomic treatments. Its potential usefulness was evaluated, as most of the other characters traditionally used to distinguish Ortgiesia species rely on measurements of flowers and sepals (Smith and Downs, 1979), which are highly polymorphic and lacking a clear pattern of variation among taxa (Wanderley and Martins, 2007). For each species, the morphological data were scored from published data (Reitz, 1983; Smith and Downs, 1979; Wanderley and Martins, 2007) and personal observations, and mapped against the NJ tree.

\subsection{Biogeography}

Habitat preference and occurrence data were studied to further explore and discuss biogeographical patterns in Aechmea subgenus Ortgiesia. Habitat preference of Ortgiesia species was coded following the different phyto-physiognomies recognized for the Brazilian Atlantic rainforest (IBGE, 2006) with some modifications, identifying five main areas of occurrence: ombrophilous forest, mixed forest, semi-deciduous forest, highland (grasslands), and sandy coastal plain ('restinga') (Fig. 2). Distribution data was obtained from field collections of each individual included in the analysis. These data were mapped against the $\mathrm{NJ}$ tree.

The number of species occurring in each latitudinal range was scored to identify the region that presents the greatest species 
richness, based on the distribution data obtained from field collections and the online database of major Brazilian herbaria, speciesLink (http://www.splink.org.br). Based on the data collected we arbitrarily divided the species as occurring southern or northern $25^{\circ} \mathrm{S}$, or in both regions, and mapped this information on the $\mathrm{NJ}$ tree.

\section{Results}

\subsection{Interspecific relationships and genetic differentiation}

AFLP profiles generated with eleven AFLP primer pairs for 96 Ortgiesia accessions yielded a data matrix comprising 942 fragments, and 1008 fragments including the outgroup. The number of scored fragments per primer pair ranged from 70 ( $\mathrm{H}$-ACC and $M$-CAG) to 123 (H-ACT and $M-C A G$ ), with an average of 93.8 fragments per primer combination.

The NJ analysis shows a tree with a backbone of short branches lacking bootstrap support greater than 50\% (Fig. 3). The Bayesian analysis produced a consensus tree with limited resolution (Fig. S1). Overall, the same clusters as in the NJ tree were recovered in Bayesian analysis, and the majority of them with higher support values (posterior probabilities, PP). All accessions of A. recurvata formed a well-supported cluster (BS 90, PP 0.99). Likewise, all examined accessions of $A$. comata formed a cluster, receiving low statistical support in the Bayesian tree (PP 0.8). A. winkleri accessions clustered together in the NJ analysis with no statistical support, while in the Bayesian analysis five out of eight individuals formed a cluster with low posterior probability (PP 0.85). In the $\mathrm{NJ}$ tree, three accessions of $A$. gamosepala (SDF 154, MAT 421,
MAT 422) formed a supported cluster (BS 78, PP 0.99), and one examined accession (SDF 156) was found nested within a cluster comprised of three accessions of $A$. caudata (ILH 56, LAU 59, GAR 08), which remained unsupported. In the Bayesian tree, accession SDF 156 was recovered in a sister position (PP 0.88) to the clade formed by $A$. caudata described above, some $A$ coelestis accessions and one A. candida. Three other A. caudata accessions (FLO 266, FLO 239, ARA 170) formed a second cluster (PP 0.98). Relationships between the two clusters of $A$. caudata remained unclear due to lack of support in both $\mathrm{NJ}$ and Bayesian trees.

In the $\mathrm{NJ}$ tree six accessions of $A$. gracilis formed a cluster, yet three additional accessions (IPO 238, IPO 284, SGR 396) were found in a cluster together with one accession each of $A$. cylindrata, A. kertesziae, and A. organensis (unsupported). Four accessions of A. sp. formed a weakly supported cluster (BS 53), and one accession of $A$. sp. (TAP 314) clustered together with one accession of A. organensis (TER). Six accessions of $A$. organensis formed a cluster, and two accessions were found in other clusters within the NJ tree (see above). In the Bayesian tree, three accessions of $A$. gracilis clustered together (SGR 386, SGR 392, and SGR 407; PP 1). This cluster was recovered in sister position (PP 0.8) to a group formed by five individuals of $A$. coelestis plus one of $A$. organensis. Two accessions of $A$. gracilis (PAR 02 and PAR 07) clustered together (PP 0.99) in a sister position to the clade formed by $A$. gamosepala (PP 0.98). A gracilis accession IPO 283 clustered with A. cylindrata and one A. organensis (PP 0.75), while A. gracilis IPO 284 clustered with A. winkleri COR 130 (PP 0.61). Bayesian analysis recovered a cluster moderately supported (PP 0.78 ) formed by all $A$. sp. accessions, while no cluster with more than two individuals were observed for A. organensis.

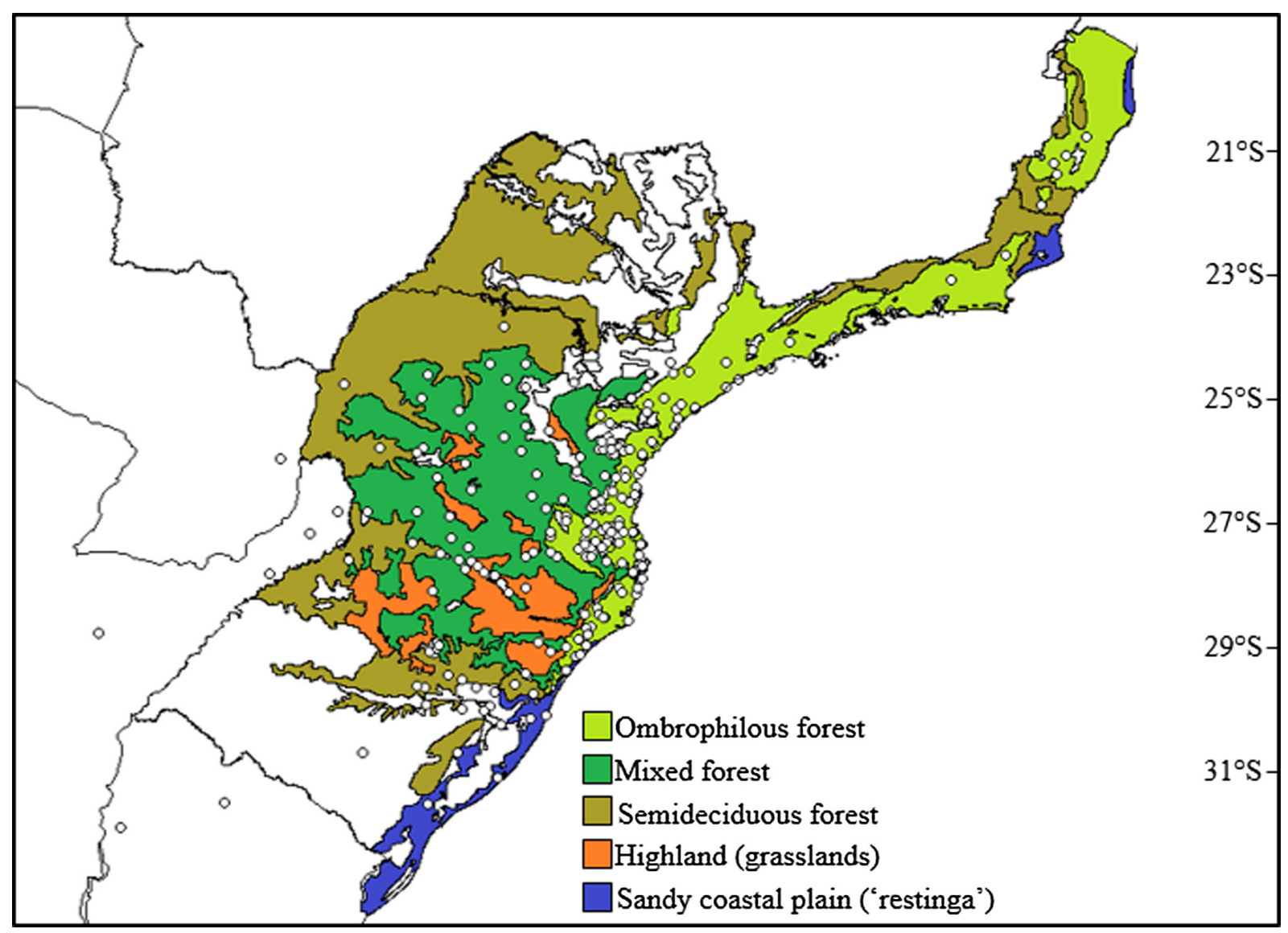

Fig. 2. Distribution of Aechmea subgenus Ortgiesia (represented by white circles accordingly to herbaria records) in the different Atlantic rainforest phyto-physiognomies. 


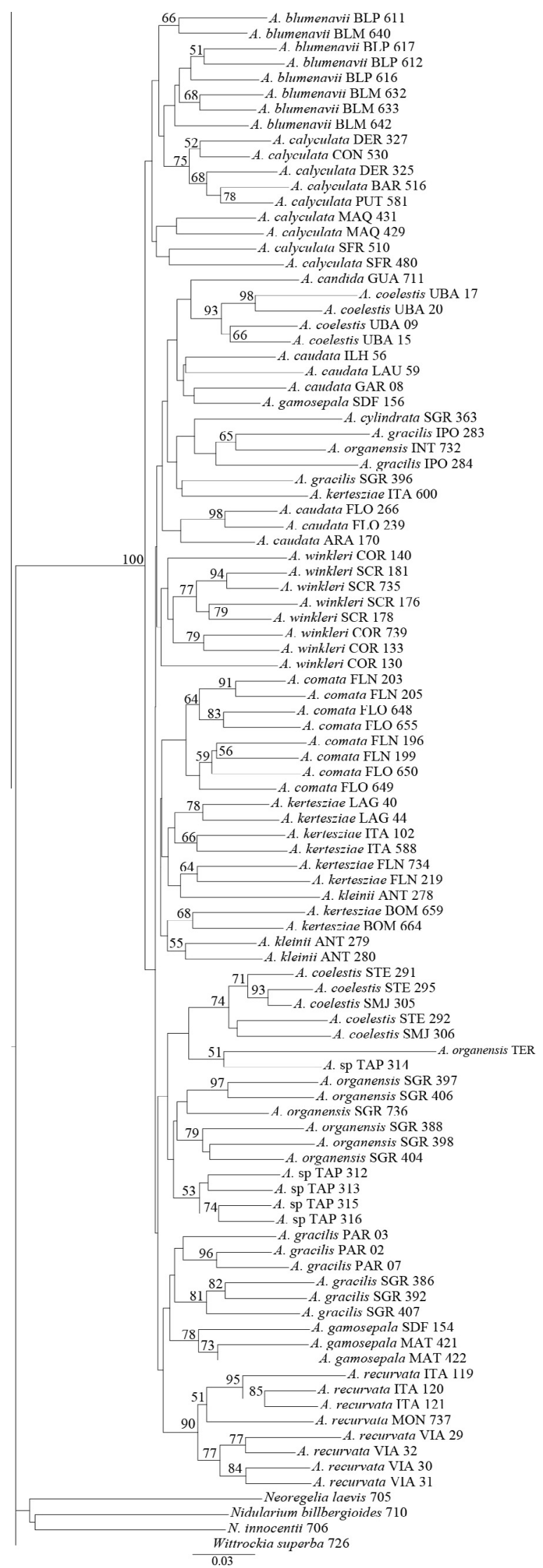

Fig. 3. Neighbor-joining tree of 96 Aechmea subgenus Ortgiesia accessions plus outgroup based on Nei and Li (1979) distances of 1008 AFLP characters obtained with eleven primer pair combinations. Bootstrap values $(>50)$ are shown above branches. The similarity scale is indicated by a horizontal bar.
Aechmea coelestis formed two supported clusters in both trees. One of these clusters received high statistical support (BS 93, PP 1 ), while the other received moderate support in the $\mathrm{NJ}$ tree (BS 74) and high in Bayesian tree (PP 1), although one accession of $A$. organensis was nested within it. However, relationships between these two clusters of $A$. coelestis remained unclear due to a lack of statistical support. Aechmea candida was recovered in sister group position to one of the A. coelestis clusters (PP 0.86). Six accessions of $A$. kertesziae clustered together, with one accession of $A$. kleinii (ANT 278) nested within this cluster in the NJ tree. A second cluster of $A$. kertesziae comprised of two accessions (BOM 659, BOM 664 ) formed a cluster with two other accessions of $A$. kleinii (ANT 279, ANT 280), yet these relationships remained unsupported. In the Bayesian tree, neither A. kertesziae nor A. kleinii formed a cluster with more than two individuals. Aechmea calyculata formed two clusters in the $\mathrm{NJ}$ analysis and one in the Bayesian analysis. The cluster which was moderately supported (BS 75) in the NJ was highly supported in the Bayesian tree (PP 0.92). The relationships of the two clusters of $A$. calyculata recovered in the $\mathrm{NJ}$ tree remained unclear due to a lack of support. In the $\mathrm{NJ}$ analysis, six accessions of $A$. blumenavii clustered together, and other two accessions (BLP 611, BLM 640) formed a moderately supported cluster (BS 68). Relationships between these two A. blumenavii clusters remained unclear due to a lack of statistical support. In the Bayesian tree, five out of eight accessions of $A$. blumenavii clustered together, with moderate statistical support (PP 0.62), yet a second cluster formed by individuals BLP 611 and BLM 640 (PP 1) was recovered, but relationships between these two clusters remained unclear due to a lack of support.

AMOVA analysis revealed that only $10.4 \%$ of the total genetic variation was found among species $\left(F_{\mathrm{CT}}=0.104 ; P<0.001\right), 13.9 \%$ among populations within species $\left(F_{\mathrm{ST}}=0.244 ; P<0.001\right)$ and $75.7 \%$ within populations $\left(F_{\mathrm{SC}}=0.156 ; P<0.001\right)$.

\subsection{Morphological character mapping}

The three selected morphological characters were mapped against the $\mathrm{NJ}$ tree to examine their taxonomic value (Fig. 4). A majority of species in Aechmea subgenus Ortgiesia have yellow (seven species) or blue petals (six species). Aechmea candida possesses white petals while A. recurvata has pink petals (Fig. 4). Most of the species in Ortgiesia possess simple inflorescences (eight species), and five species have compound inflorescences. For two species, A. gracilis and A. sp., both character states have been reported (Smith and Downs, 1979; Wanderley and Martins, 2007). Simple inflorescences can be ellipsoid, subcylindric, or cylindric in shape in Ortgiesia whereas compound inflorescences are always pyramidal. Pyramidal is the most frequent inflorescence shape within the subgenus (five species) (Fig. 4).

\subsection{Biogeography}

All Ortgiesia individuals sampled in our study were found in ombrophilous forest with the exception of $A$. winkleri, which is restricted to mixed and semi-deciduous forests. The only individual of $A$. cylindrata included in our analyses is from mixed forests. Eight species were found only in ombrophilous forest (A. blumenavii, A. candida, A. coelestis, A. comata, A. gamosepala, A. kertesziae, A. kleinii, and A. sp.). A. recurvata inhabits four habitats included in this study (all but semi-deciduous forests), and A. calyculata occurs in all habitats except for sandy coastal plains (Fig. 5).

Aechmea subgenus Ortgiesia is found from latitude $19^{\circ} \mathrm{S}$ to $32^{\circ} \mathrm{S}$ where a lot of the species co-occur (Fig. 6). However, most of the species are distributed at latitudes between $26^{\circ}$ and $27^{\circ} \mathrm{S}$, which indicates this region as the center of diversity for the subgenus. 
Petal color
$\square$ Yellow
$\square$ White
$\square$ Blue
$\square$ Pink

Inflorescence type

$\square$ Simple

Compound

Inflorescence shape

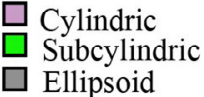

Ellipsoid

Pyramidal

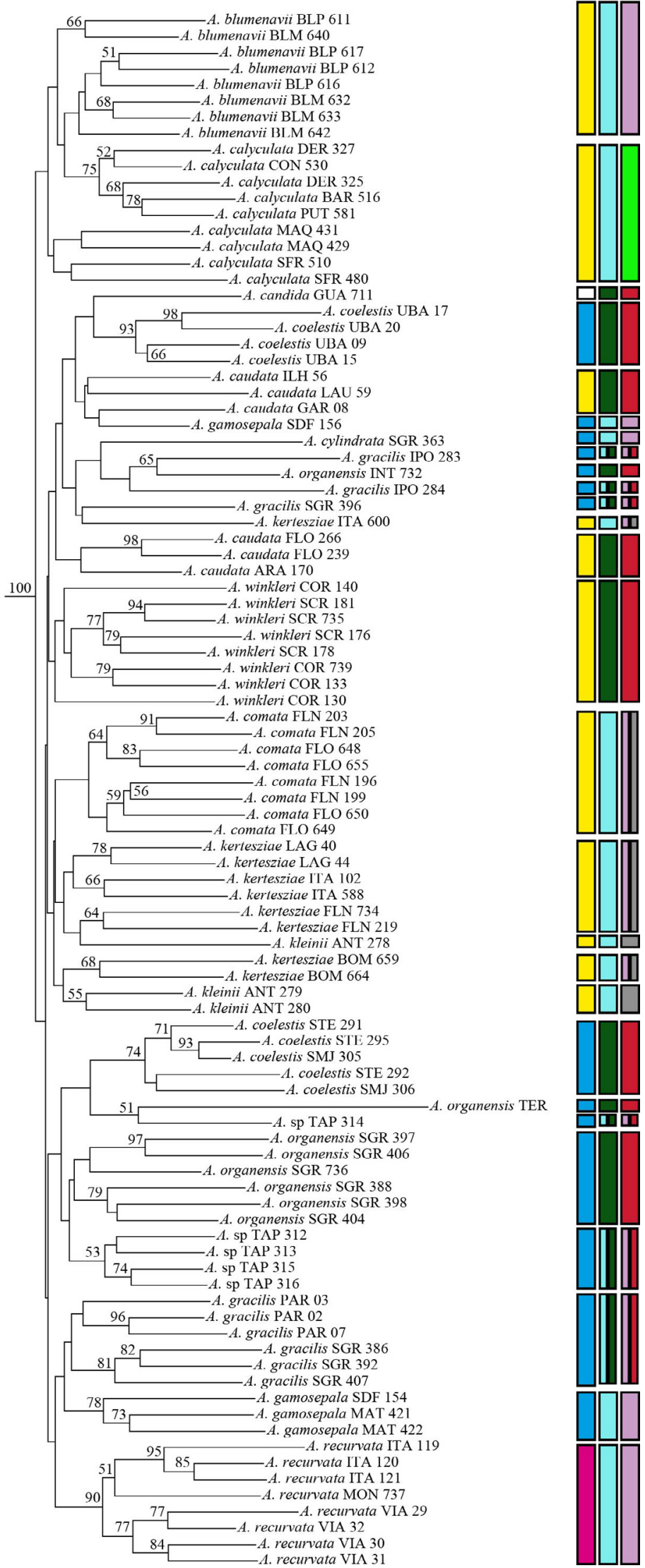

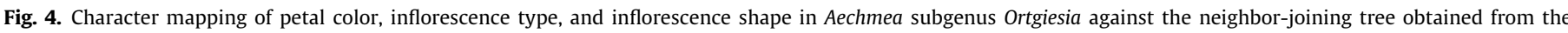

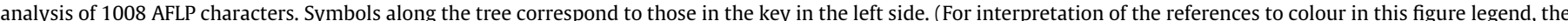
reader is referred to the web version of this article.) 
Phyto-physiognomies of Atlantic rainforest

$\square$ Ombrophilous forest

$\square$ Mixed forest

$\square$ Semideciduous forest

$\square$ Highland (grasslands)

$\square$ Sandy coastal plain (restinga)

Latitudinal range of occurence

$\square$ Southern $25^{\circ} \mathrm{S}$

Northen $25^{\circ} \mathrm{S}$

$\square$ Both

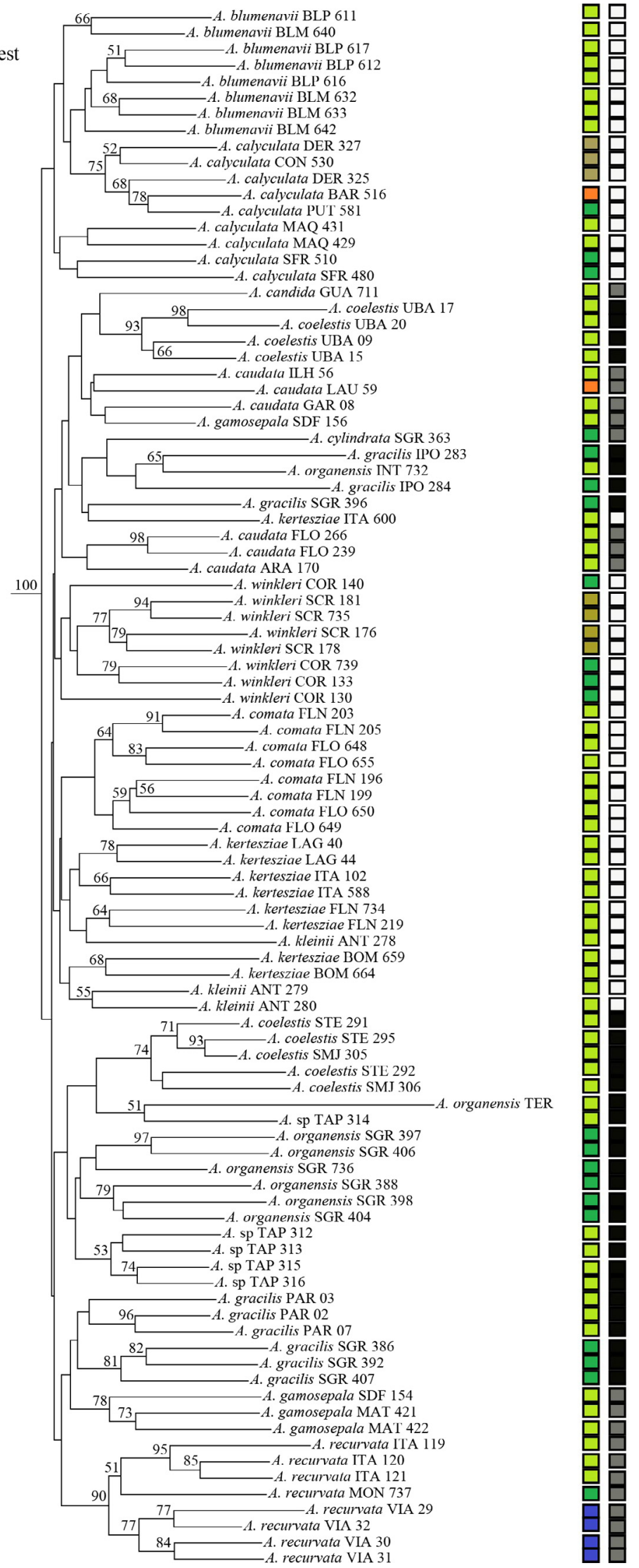

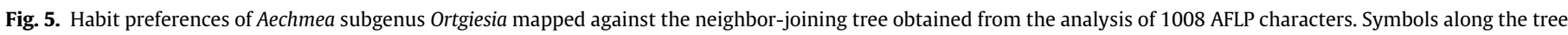
correspond to those in the legend at the left side. 
Aechmea comata and $A$. kleinii are narrow endemics, only occurring at the latitude of $27^{\circ} \mathrm{S}$, while $A$. winkleri exhibits a disjunct geographical distribution (occurring at latitudes of $26^{\circ}$ and $29^{\circ} \mathrm{S}$ ). Aechmea coelestis is the species which extents most to the northeast $\left(19^{\circ} \mathrm{S}\right)$ whereas $A$. recurvata was the most southerly distributed species with a latitude of $32^{\circ} \mathrm{S}$ (Fig. 6). There is some evidence of geographical separation in subgenus Ortgiesia when the results of latitudinal range occurrence are analyzed (Fig. 5). A. coelestis, A. gracilis, A. organensis, and A. sp. only occur northern of $25^{\circ}$, while A. blumenavii, A. calyculata, A. comata, A. kertesziae, A. kleinii, and $A$. winkleri are found southern this latitude. This pattern suggests that species with yellow petals are predominantly found in southern Atlantic rainforest, while species with blue petals are more frequent at the northern region.

\section{Discussion}

In this study we used 11 AFLP primer combinations to investigate interspecific relationships in Aechmea subgenus Ortgiesia. Our results showed that Ortgiesia species exhibit a shallow genetic divergence, which was evidenced by short internal branches in the NJ tree (Fig. 3). Although Ortgiesia species possess considerable morphological and ecological differences (Reitz, 1983; Smith and Downs, 1979), only three of the 14 included species were recovered as monophyletic lineages, and from these three clusters, only $A$. recurvata received statistical support in both Bayesian and $\mathrm{NJ}$ trees (Fig. 3, Fig. S1). Aechmea recurvata is a morphologically distinctive taxon within Ortgiesia, being the only species that possesses pink flowers and a nested inflorescence (Reitz, 1983; Smith and Downs, 1979).

AMOVA analysis revealed that only $10.4 \%$ of the genetic variation found in the data set is due to species-level differences whereas $75.7 \%$ was found within populations. This low ratio of among-versus within-species differentiation in the context of considerable morphological and ecological divergence is indicative of a recent diversification (Gaudeul et al., 2012; Turner et al., 2013). In fact, Aechmea subgenus Ortgiesia diversification started as recent as $2.5 \mathrm{Ma}$ (Silvestro et al., 2014).

Bromeliaceae represents a well known example of a species radiation (Benzing, 2000). Several groups found in the Brazilian Atlantic rainforest have been shown to have undergone a rapid diversification process e.g., Aechmea (Schulte et al., 2005, 2009), Alcantarea (Versieux et al., 2012), Dyckia (Krapp et al., 2014), and Lymania (De Sousa et al., 2007). Establishing interspecific relationships in groups where the diversification process was fast is challenging, especially if it was a recent phenomenon. Our NJ tree showed a backbone lacking bootstrap support greater than $50 \%$ (Fig. 3). In groups that have recently radiated, evolutionary processes such as introgression/hybridization and/or incomplete lineage sorting/retention of ancestral polymorphism may hamper the reconstruction of interspecific relationships and can lead to low support values in phylogenetic reconstructions (e.g., Glor, 2010; Hinsinger et al., 2014; Sauer and Hausdorf, 2010; Vitales et al., 2014).

Although artificial hybrids are easily produced within Bromeliaceae (e.g., Vervaeke et al., 2004), the occurrence of natural hybrids are rare within the family (Wendt et al., 2008). So far, little is known about the extent of natural hybridization or introgression in Aechmea subgenus Ortgiesia. However, hybrid species were recognized during the evolution of other species of Bromeliaceae, as in the genus Puya (Jabaily and Sytsma, 2010; Schulte et al., 2010). In the presence of weak reproductive isolation and shallow genetic divergence in Aechmea subgenus Ortgiesia, the occurrence of hybridization cannot be ruled out.

Retention of ancestral polymorphisms between species increases with decreased time between speciation events (Maddison, 1997; Rosenberg, 2003). Aechmea species underwent rapid and recent diversification (Givnish et al., 2011; Schulte et al., 2009; Silvestro et al., 2014) and the occurrence of incomplete lineage sorting may have been a common feature, leading to retention of ancestral polymorphisms. In plant species with long generation times and large population size, the retention of ancestral polymorphism would be favored (Bouillé and Bousquet, 2005). Species of Aechmea are known as investing in clonal reproduction (Benzing, 2000; Izquierdo and Pinero, 2000; Loh et al., 2015), which thus increases generation time, promoting the overlap of many generations (Orive, 1993; Young et al., 1996). Clonal reproduction then may slow down the loss of genetic diversity through genetic drift (as suggested for some bromeliads; Goetze et al., 2015; Izquierdo and Pinero, 2000; Loh et al., 2015; Ribeiro et al., 2013), also favoring the retention of ancestral polymorphisms (Bouillé and Bousquet, 2005). Furthermore, early in the speciation process, lineages may share ancestral polymorphisms and the differences that exist may be in a few genes with large effect, which may be responsible for morphological and ecological adaptation (Sedeek et al., 2014; Wu, 2001). Therefore, these evolutionary processes discussed might be responsible for the low resolution of the phylogenetic reconstructions recovered for Aechmea subgenus Ortgiesia.

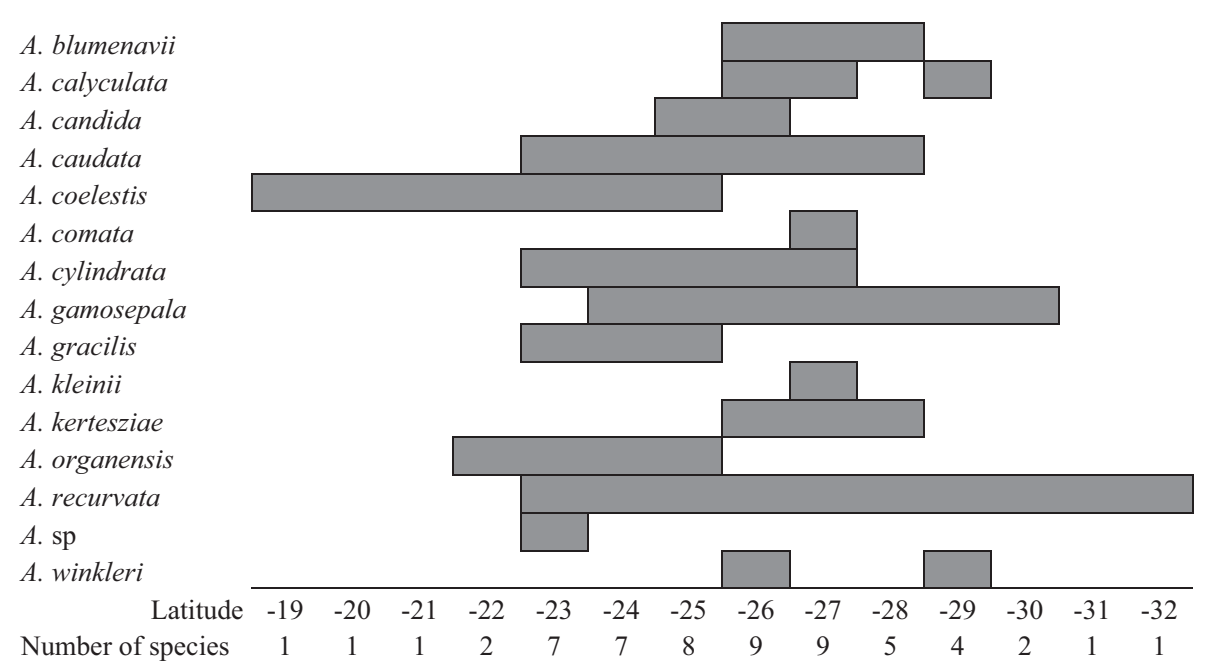

Fig. 6. Number of Aechmea subgenus Ortgiesia species occurring in each latitudinal range and their distribution. 
In spite of relatively shallow genetic divergence and low bootstrap support for the main clusters recovered in the $\mathrm{NJ}$ tree, and the low resolution of the Bayesian tree, most of the accessions of each species clustered together. Some of these clusters are characterized by morphology and/or ecological data. For example, Aechmea comata, A. kertesziae and A. kleinii clustered together. These species present similar morphology and their geographical distribution is restricted to Santa Catarina state (Reitz, 1983; Smith and Downs, 1979). While $A$. comata and $A$. kertesziae thrive at sea level and can be found in sympatry, A. kleinii occurs at altitudes above $1000 \mathrm{~m}$ from sea level and is the only Ortgiesia species with nocturnal anthesis (Reitz, 1983).

Aechmea winkleri accessions clustered together in the $\mathrm{NJ}$ tree. Aechmea winkleri and A. caudata are the only yellow-flowered species with compound inflorescences within Ortgiesia, but the former is reduced in size in many morphological characters when compared to the latter and is not found in coastal regions (Smith and Downs, 1979; Fig. 4). Only two populations of A. winkleri are known to date, which seem to be geographically isolated from the remaining Ortgiesia species (Fig. 1). Despite of the geographical isolation from the other Ortgiesia, A. winkleri wild population from Rio Grande do Sul has high levels of genetic diversity and no signs of demographic contractions were observed (Goetze et al., 2015).

Almost all accessions of the possible new taxon included in this study were recovered in a weakly to moderate supported clade (Fig. 3, Fig. S1). Aechmea sp. is seen as distinct taxon from the closely related $A$. organensis especially because of the inflorescence type, in general simple, rarely compound, and due to differences in placentation, with placentae positioned along the ovary in $A$. sp. while in A. organensis it is almost always restricted to the central region of the ovary (Wanderley and Martins, 2007). These authors stated $A$. sp. is possibly a new taxon, although further studies are required before conclusions can be drawn about its validity.

The AFLP technique is a multi-locus approach, covering the entire genome, which is a desirable feature. Moreover, AFLPs have been used successfully to resolve interspecific relationships in recently diverged and radiated groups (Althoff et al., 2007; Bussell et al., 2005; García-Pereira et al., 2010; Koopman, 2005), especially when other molecular marker failed to resolve them (Vitales et al., 2014, and references therein). The patterns recovered in the present study may reflect the recent and rapid diversification of Aechmea subgenus Ortgiesia as already observed for the entire core bromelioids (e.g., Schulte et al., 2009; Silvestro et al., 2014). Markers with a deeper sampling in the genome, as those generated by next generation sequencing, may be used in further studies to clarify interspecific relationships in Aechmea subgenus Ortgiesia. The next step would be to further elucidate the phylogenetic placement of Ortgiesia within the core bromelioids including the identification of monophyletic lineages, which will require a broader sampling within the group.

\subsection{Evaluation of morphological characters}

The mapping of three selected traits against the $\mathrm{NJ}$ tree suggests that independent evolution events may have occurred (Fig. 4). Petal color and inflorescence type may not constitute synapomorphies, although they have been used as the main characters to distinguish between Aechmea subgenus Ortgiesia species (Smith and Downs, 1979). Similarly, inflorescence shape showed substantial homoplasy when mapped against the $\mathrm{NJ}$ tree, which implies that this character has limited taxonomic value in the subgenus. High levels of homoplasy in characters often used to distinguished species of Aechmea were previously highlighted in a morphological study (Faria et al. 2004), which have been considered a consequence of the rapid diversification of the group (Faria et al., 2004; Schulte et al., 2009).

\subsection{Biogeography}

Our analysis of habitat preferences showed that the majority of Ortgiesia species occur in ombrophilous forest (Fig. 5). This phytophysiognomy is found near the Brazilian coastal line and receives the greatest amount of rainfall per year in the Atlantic rainforest domain (Oliveira-Filho and Fontes, 2000). Therefore, the occurrence of most of the Aechmea subgenus Ortgiesia in this region is probably a result of a higher humidity, a pattern already observed in other Brazilian plant groups, which often are floristically more diverse close to the sea (Oliveira-Filho and Fontes, 2000). The number of Ortgiesia species found in other phyto-physiognomies decreases with increasing distance from the coastal line and which thus receive less rainfall (e.g., mixed forest presents seven species and semi-deciduous forest three). In the highlands (grasslands) the number of species is also smaller (where only three Ortgiesia species are found), and this pattern may occur not only due to drier conditions but also because of the decrease in temperature (the highlands are the coolest regions in Brazil; Safford, 1999). Aechmea recurvata is the only species that occurs in all phytophysiognomies, which thus highlights the ability of this species to deal with different climatic conditions.

Today, the greatest species richness in Ortgiesia is found at latitudes between $26^{\circ}$ and $27^{\circ} \mathrm{S}$, thus rendering the south of Brazilian Atlantic rainforest the center of diversity for the subgenus (Fig. 6). In previous studies examining the patterns and processes that promoted diversification within the Brazilian Atlantic rainforest, the southern part of the biome had received little attention. Among the studies which consider diversification processes in Brazilian Atlantic rainforest, and which mainly focused on animal taxa, several point to a recent colonization of the southern region (e.g., Carnaval and Moritz, 2008; D'Horta et al., 2011; Fitzpatrick et al., 2009; Palma-Silva et al., 2009; Turchetto-Zolet et al., 2012), whereas others found early divergent lineages occurring in the south (e.g., Grazziotin et al., 2006; Thomé et al., 2010; Valdez and D’Elía, 2013). Our results favor the second scenario for Ortgiesia, as most of the species occur in the south as well as many endemics and narrow endemic species can be found in this region of the Brazilian Atlantic rainforest (Fig. 6).

The latest molecular phylogeny of subfamily Bromelioideae suggests that the crown diversification in Ortgiesia started at around $2.5 \mathrm{Ma}$, which implies that Pleistocene climatic oscillations may have affected the distribution pattern of the species (Silvestro et al., 2014). Palynological studies revealed that during this period in south and southeastern Brazil, forest distribution was strongly affected by the decrease in temperature and drier conditions, restricting the occurrence of forest to small refugial areas in deep valleys or to more humid areas along rivers. At the beginning of the Holocene there was a significant increase in temperature and humidity, which allowed forest expansion (Behling and Negrelle, 2001; Behling and Pillar, 2007; Behling et al., 2004). These shifts in vegetation range may have fragmented species distributions leading to geographical isolation and in some cases population differentiation. The topography of southern Brazil, with many mountain chains and valleys probably provided many areas for Atlantic rainforest species to persist during the climatic oscillations of the Pleistocene. Therefore, the geographical isolation imposed by this scenario could have been a driver for allopatric speciation in Ortgiesia and for other species. This would explain the narrow endemics (A. comata, A. kleinii, and $A$. sp.) as well as the many species with restricted distribution (A. blumenavii, A. gracilis, A. kertesziae, A. organensis, and $A$. winkleri) and the disjunct pattern of occurrence observed for A. winkleri. 


\section{Conclusions}

Our analysis with 11 AFLP primer combinations showed that Aechmea subgenus Ortgiesia exhibits a shallow genetic divergence among species, despite morphological and ecological divergence. This study provided the first insights into Ortgiesia evolution, confirming its recent origin and revealing that hybridization and/or incomplete lineage sorting may hamper the reconstruction of interspecific relationships. Further studies should make use of a deeper genome sampling as well as increase the sampling inside the core bromelioid clade to investigate the position of Ortgiesia within this lineage, assess its monophyly and to further elucidate interspecific relationships.

Mapping petal color, inflorescence type and inflorescence shape against the $\mathrm{NJ}$ tree indicated that these characters possess different levels of homoplasy, which implies a limited taxonomic value within Ortgiesia.

The biogeographic characterization showed that most of the Ortgiesia species occur at ombrophilous forest. The southern region of Brazilian Atlantic rainforest was considered the center of diversity for the group, as most of the species occur between latitudes of $26^{\circ}$ and $27^{\circ} \mathrm{S}$. The shifts in vegetation ranges imposed by the climatic oscillation of the Pleistocene may have fragmented the distribution of the species and likely caused geographical isolation, which might have been a driver for allopatric speciation in Aechmea subgenus Ortgiesia.

\section{Acknowledgments}

We thank Ademir Reis, André Jasper, Bruna Abonanza, Christian R. Rohr, Felipe G. Pinheiro, Gecele M. Paggi, Manuela Bruxel, Maria C. Medeiros, Maria G. L. Wanderley, Mauricio P. Almerão, Murilo A. Nichele, Rafael B. Louzada, Rafael V. B. Moreira, Suzana E. Martins, Tânia Wendt, Talisson R. Capistrano, and Tiago Coser for help with sampling; Melissa Harrison for laboratory assistance; Aline P. Lorenz-Lemke, Andreia C. Turchetto-Zolet, and Gecele M. Paggi for helpful discussions; and Darren Crayn for his valuable suggestions on an earlier version of the manuscript. We also would like to thank to Instituto Brasileiro do Meio Ambiente e dos Recursos Naturais Renováveis (IBAMA) and state departments of environment for processing of collection and export permits. This study was supported by Conselho Nacional de Desenvolvimento Científico e Tecnológico (CNPq - 479413/ 2011-8), Fundação de Amparo à Pesquisa do Estado do Rio Grande do Sul (FAPERGS - Pronex 10/ 0198-0 and PqG 06/ 2010 - 1015348), Fundação de Amparo à Pesquisa do Estado de São Paulo (FAPESP 2009/ 52725-3), Australian Tropical Herbarium, James Cook University (ATH - JCU), and Programa de Pós-Graduação em Genética e Biologia Molecular, Universidade Federal do Rio Grande do Sul (PPGBM - UFRGS). M. Goetze received research fellowship from CNPq (142124/ 2010-9 and 237012/ 2012-0).

\section{Appendix A. Supplementary material}

Supplementary data associated with this article can be found, in the online version, at http://dx.doi.org/10.1016/j.ympev.2016.03. 001.

\section{References}

Althoff, D.M., Gitzendanner, M.A., Segraves, K.A., 2007. The utility of amplified fragment length polymorphisms in phylogenetics: a comparison of homology within and between genomes. Syst. Biol. 56, 477-484.

Barfuss, M.H.J., Samuel, R., Till, W., Stuessy, T.F., 2005. Phylogenetic relationships in subfamily Tillandsioideae (Bromeliaceae) based on DNA sequence data from seven plastid regions. Am. J. Bot. 92, 337-351.
Behling, H., Negrelle, R.R.B., 2001. Tropical rain forest and climate dynamics of the Atlantic lowland, southern Brazil, during the Late Quaternary. Quaternary Res. 56, 383-389.

Behling, H., Pillar, V.D., 2007. Late Quaternary vegetation, biodiversity and fire dynamics on the southern Brazilian highland and their implication for conservation and management of modern Araucaria forest and grassland ecosystems. Philos. T. R. Soc. B 362, 243-251.

Behling, H., Pillar, V.D., Orlóci, L., Bauermann, S.G., 2004. Late Quaternary Araucaric forest, grassland (Campos), fire and climate dynamics, studied by highresolution pollen, charcoal and multivariate analysis of the Cambará do Sul core in southern Brazil. Palaeogeogr. Palaeocl. 203, 277-297.

Benzing, D.H., 2000. Bromeliaceae: Profile of an Adaptive Radiation. Cambridge University Press, Cambridge.

Bouillé, M., Bousquet, J., 2005. Trans-species shared polymorphisms at orthologous nuclear gene loci among distant species in the conifer Picea (Pinaceae): implications for the long-term maintenance of genetic diversity in trees. Am. J. Bot. 92, 63-73.

Bussell, J.D., Waycott, M., Chappill, J.A., 2005. Arbitrarily amplified DNA markers as characters for phylogenetic inference. Perspect. Plant Ecol. Evol. Syst. 7, 3-26.

Carnaval, A.C., Moritz, C., 2008. Historical climate modeling predicts patterns of current biodiversity in the Brazilian Atlantic forest. J. Biogeogr. 35, 1187-1201.

D’Horta, F.M., Cabanne, G.S., Meyer, D., Miyaki, C., 2011. The genetic effects of Late Quaternary climatic changes over a tropical latitudinal gradient: diversification of an Atlantic Forest passerine. Mol. Ecol. 20, 1923-1935.

De Sousa, L.O.F., Wendt, T., Brown, G.K., Tuthill, D.E., Evans, T.M., 2007. Monophyly and phylogenetics relationships in Lymania (Bromeliaceae: Bromelioideae) based on morphology and chloroplast DNA sequences. Syst. Bot. 32, 264-270.

Doyle, J.J., Doyle, J.L., 1990. Isolation of plant DNA from fresh tissue. Focus 12, $13-$ 15.

Excoffier, L., Laval, G., Schneider, S., 2005. Arlequin ver. 3.0: an integrated software package for population genetics data analysis. Evol. Bioinform. Online 1, 47-50.

Faria, A.P.G., Wendt, T., Brown, G.K., 2004. Cladistic relationships of Aechmed (Bromeliaceae, Bromelioideae) and allied genera. Ann. Mo. Bot. Gard. 91, 303319.

Felsenstein, J., 1985. Confidence limits on plylogenies: an approach using the bootstrap. Evolution 39, 789-791.

Fitzpatrick, S.W., Brasileiro, C.A., Haddad, C.F.B., Zamudio, K.R., 2009. Geographical variation in genetic structure of an Atlantic Coastal Forest frog reveals regional differences in habitat stability. Mol. Ecol. 18, 2877-2896.

García-Pereira, M.J., Caballero, A., Quesada, H., 2010. Evaluating the relationship between evolutionary divergence and phylogenetic accuracy in AFLP data sets. Mol. Biol. Evol. 27, 988-1000.

Gaudeul, M., Rouhan, G., Gardner, M.F., Hollingsworth, P.M., 2012. AFLP markers provide insights into the evolutionary relationships and diversification of New Caledonian Araucaria species (Araucariaceae). Am. J. Bot. 99, 68-81.

Givnish, T.J., Barfuss, M.H.J., Van Ee, B., Riina, R., Schulte, K., Horres, R., Gonsiska, P.A., Jabaily, R.S., Crayn, D.M., Smith, J.A.C., Winter, K., Brown, G.K., Evans, T.M., Holst, B.K., Luther, H., Till, W., Zizka, G., Berry, P.E., Sytsma, K., 2011. Phylogeny, adaptive radiation, and historical biogeography in Bromeliaceae: insights from an eight-locus plastid phylogeny. Am. J. Bot. 98, 872-895.

Glor, R.E., 2010. Phylogenetic insights on adaptive radiation. Annu. Rev. Ecol. Evol Syst. 41, 251-270.

Goetze, M., Büttow, M.V., Zanella, C.M., Paggi, G.M., Bruxel, M., Pinheiro, F.G. Sampaio, J.A.T., Palma-Silva, C., Cidade, F.W., Bered, F., 2015. Genetic variation in Aechmea winkleri, a bromeliad from na inland Atlantic rainforest fragment in Southern Brazil. Biochem. Syst. Ecol. 58, 204-210.

Grazziotin, F.G., Monzel, M., Echeverrigaray, S., Bonatto, S.L., 2006. Phylogeography of the Bothrops jararaca complex (Serpentes: Viperidae): past fragmentation and island colonization in the Brazilian Atlantic Forest. Mol. Ecol. 15, 39693982.

Hinsinger, D.D., Gaudeul, M., Couloux, A., Bousquet, J., Frascaria-Lacoste, N., 2014 The phylogeography of Eurasian Fraxinus species reveals ancient transcontinental reticulation. Mol. Phylogenet. Evol. 77, 223-237.

Heller, S., Leme, E.M., Schulte, K., Benko-Issepon, A.M., Zizka, G., 2015. Elucidating phylogenetic relationships in the Aechmea alliance: AFLP analysis of Portea and the Gravisia complex (Bromeliaceae, Bromelioideae). Syst. Bot. 40, 716-725.

Horres, R., Schulte, K., Weising, K., Zizka, G., 2007. Systematics of Bromelioideae (Bromeliaceae) - evidence from molecular and anatomical studies. Aliso 23, 27-43.

IBGE - Instituto Brasileiro de Geografia e Estatística, 2006. Mapa da área de aplicação da Lei n¹1.428 de 2006.

Izquierdo, L.Y., Pinero, D., 2000. High genetic diversity in the only known population of Aechmea tuitensis (Bromeliaceae). Aust. J. Bot. 48, 645-650.

Jabaily, R.S., Sytsma, K.J., 2010. Phylogenetics of Puya (Bromeliaceae): placement major lineages, and evolution of Chilean species. Am. J. Bot. 97, 337-356.

Jabaily, R.S., Sytsma, K.J., 2013. Historical biogeography and life-history evolution of Andean Puya (Bromeliaceae). Bot. J. Linn. Soc. 171, 201-224.

Koopman, W.J.M., 2005. Phylogenetic signal in AFLP data sets. Syst. Biol. 54, $197-$ 217.

Krapp, F., Pinangé, D.S.B., Benko-Iseppon, A.M., Leme, E.M.C., Weising, K., 2014 Phylogeny and evolution of Dyckia (Bromeliaceae) inferred from chloroplast and nuclear sequences. Plant Syst. Evol. 300, 1591-1614.

Loh, R., Scarano, F.R., Alves-Ferreira, M., Salgueiro, F., 2015. Clonality strongly affects the spatial genetic structure of the nurse species Aechmea nudicaulis (L.) Griseb. (Bromeliaceae). Bot. J. Linn. Soc. 178, 329-341.

Louzada, R.B., Schulte, K., Wanderley, M.G.L., Silvestro, D., Zizka, G., Barfuss, M.H.J. Palma-Silva, C., 2014. Molecular phylogeny of the Brazilian endemic genus 
Orthophytum (Bromelioideae, Bromeliaceae) and its implications on morphological character evolution. Mol. Phylogenet. Evol. 77, 54-64.

Luther, H.E., 2010. An Alphabetical List of Bromeliad Binomials, 12th ed. Sarasota Bromeliad Society International and Marie Selby Botanical Gardens, Sarasota.

Luther, H.E., 2012. An Alphabetical List of Bromeliad Binomials, 13th ed. Sarasot Bromeliad Society International and Marie Selby Botanical Gardens, Sarasota.

Maddison, W.P., 1997. Gene trees in species trees. Syst. Biol. 46, 523-536.

Maia, V.H., Mata, C.Z., Franco, L.O., Cardoso, M.A., Cardoso, S.R.S., Hermerly, A.S., Ferreira, P.C.G., 2012. DNA barcoding Bromeliaceae: achievements and pitfalls. PLoS ONE 7, e29877.

Martinelli, G., Vieira, C.M., Gonzalez, M., Leitman, P., Piratininga, A., Costa, A., Forzza, R.C., 2008. Bromeliaceae da Mata Atlântica: lista de espécies, distribuição e conservação. Rodriguésia 59, 209-258.

Meudt, H.M., Clarke, A.C., 2007. Almost forgotten or latest practice? AFLP applications, analyses and advances. Trends Plant Sci. 12, 106-117.

Myers, N., Mittermeier, R.A., Mittermeier, C.G., da Fonseca, G.A.B., Kent, J., 2000 Biodiversity hotpots for conservation priorities. Nature 403, 853-858.

Nei, M., Li, W.-H., 1979. Mathematical model for studying genetic variation in terms of restriction endonucleases. Proc. Natl. Acad. Sci. USA 76, 5269-5273.

Oliveira-Filho, A.T., Fontes, M.A., 2000. Patterns of floristic differentiation among Atlantic Forests in Southeastern Brazil and the influence of climate. Biotropica 32, 793-810.

Orive, M.E., 1993. Effective population size in organisms with complex life-histories. Theor. Popul. Biol. 44, 316-340.

Palma-Silva, C., Lexer, C., Paggi, G.M., Barbará, T., Bered, F., Bodanese-Zanettini, M.H. 2009. Range-wide patterns of nuclear and cloroplast DNA diversity in Vriese gigantea (Bromeliaceae), a neotropical forest species. Heredity 103, 503-512.

Reitz, R., 1983. Bromeliáceas e a malária - bromélia endêmica. Flora Ilustrada Catarinense. Herbário Barbosa Rodrigues, Itajaí.

Rex, M., Patzolt, K., Schulte, K., Zizka, G., Vásquez, R., Ibisch, P.L., Weising, K., 2007. AFLP analysis of genetic relationships in the genus Fosterella L.B. Smith, Pitcairnioideae, Bromeliaceae. Genome 50, 90-105.

Ribeiro, M.C., Metzger, J.P., Martensen, A.C., Ponzoni, F.J., Hirota, M.M., 2009. The Brazilian Atlantic Forest: how much is left, and how is the remaining forest distributed? Implications for conservation. Biol. Conserv. 142, 1141-1153.

Ribeiro, P.C.C., Pinheiro, L.C., Domingues, R., Forzza, R.C., Machado, M.A., Viccini, L.F. 2013. Genetic diversity of Vriesea cacuminis (Bromeliaceae): an endangered and endemic Brazilian species. Genet. Mol. Res. 12, 1934-1943.

Ronquist, F., Huelsenbeck, J.P., 2003. MrBayes 3: Bayesian inference of phylogeny. Bioinformatics 19, 1572-1574.

Rosenberg, N.A., 2003. The shapes of neutral gene genealogies in two species: probabilities of monophyly, paraphyly, and polyphyly in a coalescente model Evolution 57, 1465-1477.

Safford, H.D., 1999. Brazilian Páramos I. An introduction to the physical environment and vegetation of the campos de altitude. J. Biog. 26, 693-712.

Saitou, N., Nei, M., 1987. The neighbour joining method: a new method for reconstructing phylogenetic trees. Mol. Biol. Evol. 4, 406-425.

Sass, C., Specht, C.D., 2010. Phylogenetic estimation of the core bromelioids with an emphasis on the genus Aechmea (Bromeliaceae). Mol. Phylogenet. Evol. 55, 559-571.

Sauer, J., Hausdorf, B., 2010. Reconstructing the evolutionary history of the radiation of the land snail genus Xerocrassa on Crete based on mitochondrial sequences and AFLP markers. BMC Evol. Biol. 10, 299-311.

Schulte, K., Barfuss, M.H.J., Zizka, G., 2009. Phylogeny of Bromelioideae (Bromeliaceae) inferred from nuclear and plastid DNA loci reveals the evolution of the tank habit within the subfamily. Mol. Phylogenet. Evol. 51, 327-339.

Schulte, K., Horres, R., Zizka, G., 2005. Molecular phylogeny of Bromelioideae and its implications on biogeography and the evolution of CAM in the family (Poales, Bromeliaceae). Senckenbergiana Biol. 85, 113-125.
Schulte, K., Silvestro, D., Kiehlmann, E., Vesely, S., Novoa, P., Zizka, G., 2010. Detection of recent hybridization between sympatric Chilean Puya species (Bromaliaceae) using AFLP markers and reconstruction of complex relationships. Mol. Phylogenet. Evol. 57, 1105-1119.

Schulte, K., Zizka, G., 2008. Multi locus plastid phylogeny of Bromelioideae (Bromeliaceae) and the taxonomic utility of petal appendages and pollen characters. Candollea 63, 209-225.

Sedeek, K.E.M., Scopece, G., Staedler, Y.M., Schönenberger, J., Cozzolino, S., Schiestl, F.P., Schlüter, P.M., 2014. Genic rather than genome-wide differences between sexually deceptive Ophrys orchids with different pollinators. Mol. Ecol. 23, 6192-6205.

Silvestro, D., Zizka, G., Schulte, K., 2014. Disentangling the effects of key innovations on the diversification of Bromelioideae (Bromeliaceae). Evolution 68, 163-175.

Smith, L.B., Downs, R.J., 1979. Flora Neotropica. Monograph No. 14, Part 3: Bromelioideae (Bromelioideae). Hafner, New York.

Stehmann, J.R., Forzza, R.C., Salino, A., Sobral, M., da Costa, D.P., Kamino, L.H.Y., 2009. Plantas da Floresta Atlântica. Jardim Botânico do Rio de Janeiro, Rio de Janeiro.

Swofford, D.L., 2002. PAUP*: Phylogenetic Analysis using Parsimony (* and other methods) v. 4.0b10. Sinauer Assoc., Sunderland.

Thomé, M.T., Zamudio, K.R., Giovanelli, J.G.R., Haddad, C.F.B., Baldissera, F.A., Alexandrino, J., 2010. Phylogeography of endemic toads and post-Pliocene persistence of the Brazilian Atlantic Forest. Mol. Phylogenet. Evol. 55, 10181031.

Turchetto-Zolet, A.C., Cruz, F., Vendramin, G.G., Simon, M.F., Salgueiro, F., MargisPinheiro, M., Margis, R., 2012. Large-scale phylogeography of the disjunct Neotropical tree species Schizolobium parahyba (Fabaceae-Caesalpinioideae). Mol. Phylogenet. Evol. 65, 174-182.

Turner, B., Paun, O., Munzinger, J., Duangjai, S., Chase, M.W., Samuel, R., 2013. Analyses of amplified fragment length polymorphisms (AFLP) indicate rapid radiation of Diospyros species (Ebenaceae) endemic to New Caledonia. BMC Evol. Biol. 13, 269-283.

Valdez, L., D'Elía, G., 2013. Differentiation in the Atlantic Forest: phylogeography of Akodon montensis (Rodentia, Sigmodontinae) and the Carnaval-Moritz model of Pleistocene refugia. J. Mammal. 94, 911-922.

Versieux, L., Barbará, T., Wanderley, M.G.L., Calvente, A., Fay, M.F., Lexer, C., 2012. Molecular phylogenetics of the Brazilian giant bromeliads (Alcantarea, Bromeliaceae): implications for morphological evolution and biogeography. Mol. Phylogenet. Evol. 64, 177-189.

Vervaeke, I., Wouters, J., Londers, E., Deroose, R., De Proft, M.P., 2004. Morphology of artificial hybrids of Vriesea splendens $\times$ Tillandsia cyanea and $V$. splendens $\times$ Guzmania lingulata (Bromeliaceae). Ann. Bot. Fennici 41, 201-208.

Vitales, D., García-Fernández, A., Pellicer, J., Vallès, J., Santos-Guerra, A., Cowan, R.S., Fay, M.F., Hidalgo, O., Garnatje, T., 2014. Key processes for Cheirolophus (Asteraceae) diversification on oceanic Islands inferred from AFLP data. PLoS ONE 9, e113207.

Vos, P., Hogers, R., Bleeker, M., Reijans, M., Van de Lee, T., Hornes, M., Frijters, A., Pot, J., Peleman, J., Kuiper, M., Zabeau, M., 1995. AFLP: a new technique for DNA fingerprinting. Nucleic Acids Res. 23, 4407-4414.

Wanderley, M.G.L., Martins, S.E., 2007. Bromeliaceae. In: Wanderley, M.G.L., Shepherd, G.J., Melhem, T.S., Giulietti, A.M. (Eds.), Flora fanerogâmica do estado de São Paulo. Instituto de Botânica, São Paulo, pp. 39-161.

Wendt, T., Coser, T.S., Matallana, G., Guilherme, F.A.G., 2008. An apparent lack of prezygotic reproductive isolation among 42 sympatric species of Bromeliaceae in southeastern Brazil. Plant Syst. Evol. 275, 31-41.

Wu, C.I., 2001. The genic view of the process of speciation. J. Evol. Biol. 14, 851-865.

Young, A., Boyle, T., Brown, T., 1996. The population genetic consequences of habitat fragmentation for plants. Trends Ecol. Evol. 11, 413-418. 